\title{
Effect of deficit irrigation and mulch on water use and yield of drip irrigated onions
}

\author{
A. A. Ramalan ${ }^{1}$, H. Nega ${ }^{2}$ \& M. A. Oyebode ${ }^{1}$ \\ ${ }^{I}$ Department of Agricultural Engineering, Ahmadu Bello University, \\ Nigeria \\ ${ }^{2}$ Federal Ministry of Agriculture and Rural Development, Ethiopia
}

\begin{abstract}
A field experiment was conducted at Melkassa Agricultural Research Centre in the Central Rift Valley of Ethiopia (located at latitude $8^{\circ} 24 ' \mathrm{~N}$, longitude $39^{\circ}$ $21^{\prime} \mathrm{E}$ and altitude $1,550 \mathrm{~m}$ above sea level) during the $2008 / 2009$ dry season to study the 'Effect of deficit irrigation and different mulch covers on water use and yield of drip irrigated onion (Allium Cepa L., cultivar: Bombay Red)'. A drip irrigation system with 144 laterals was used for the experiment. Two factors, namely deficit irrigation at four levels $(0,25,50$ and $75 \%$ of Total Available Water, TAW) and mulch covers of four different types (no mulch or bare soil, straw mulch, clear plastic and black plastic) were combined in a randomized complete block design and laid out as treatments in plots $0.4 \mathrm{~m} \times 5 \mathrm{~m}$. Three replications were used. Results showed that onion bulb yield decreased with increase in levels of water deficit. In contrast, both crop water use and irrigation water use efficiencies increased with increase in water deficit level. Use of mulch significantly increased bulb yield. Plots with mulch covers yielded higher than 30 t.ha $^{-1}$ compared to the bare soil yield of 28.3 t.ha $^{-1}$ (straw $>$ clear plastic $>$ black plastic $>$ bare soil). Water use was similarly reduced by the presence of mulch covers. A hydraulic performance evaluation of the drip system showed there was an average emitter flow rate variation of $13.7 \%$, a coefficient of uniformity of $85 \%$ and an overall irrigation application efficiency of $94.4 \%$.
\end{abstract}

Keywords: deficit irrigation, drip irrigation, water harvesting, mulch, irrigated onion, hydraulic performance of drip system, water use, water use efficiency. 


\section{Introduction}

The dry land area of Ethiopia which includes the Central Rift Valley accounts for $67 \%$ of the total land mass of the country (EARO [5]). Approximately, 62\% of the irrigable land of the country is located in this Valley. The major crop irrigated by farmers in the area, who are mainly smallholder and peasant, is onion. Rainfall, characteristically high intense and capable of causing erosion, rarely exceed $800 \mathrm{~mm}$; most areas receive 500-800 mm annually (MOA) [12]. Annual potential evapotranspiration is high, thus placing high evaporative demand on water surfaces. As a strategy for reducing food insecurity, encouraging small-holder farmer investment in agriculture and increased exploitation of its water resources, the government introduced rain-water harvesting and small scale drip irrigation technologies. In this regard, over 100,000 units of water harvesting structures, hand-dug wells, low cost water lifting devices, and family drip irrigation systems deployed have achieved partial success in implementation. Knowledge gaps exit regarding the correct sizing of water harvesting tank, irrigation land size relative to household tank, effective use of harvested water and the economics of the whole system. These have to be addressed in a study. For a general objective, this pioneering study sought to evaluate the effect of deficit irrigation and use of mulch covers on water use and yield of drip irrigated onion targeting resource poor smallholder farmers in moisture deficient environment.

\subsection{Deficit irrigation effects}

Deficit (or regulated deficit) irrigation scheduling is one way of maximizing water use efficiency for higher yields per unit of irrigation water applied; the crop is exposed to a certain level of water stress either during a particular period or throughout the whole growing period (FAO [8]). The expectation is that any yield reduction resulting from the water stress will be insignificant compared with the benefits gained through diverting the saved water to irrigate other crops. For deficit irrigation and its schedules to be successful, some knowledge of crop response to water stress at specific growth stage or entire season is essential. FAO [8] suggested that crops, or crop varieties most suitable for deficit irrigation are those with short growing season and are tolerant to drought. In implementing deficit irrigation, consideration must be given to soil retention capacity, as well as, modification of agronomic practices like plant population, date of planting, fertilizer application, etc.

Crop water use efficiency is the ratio of crop yield (Y) to the amount of water depleted by the crop in the process of evapotranspiration (ET) and is expressed as $\mathrm{Kg} . \mathrm{m}^{-3}$ or $\mathrm{Kg} \cdot \mathrm{ha}^{-1} \mathrm{~mm}^{-1}$. Irrigation water use efficiency, on the other hand, is a ratio of the crop yield (Y) to the total amount of water used in the field (WR). Since both the Crop and Irrigation water use efficiencies are ratios, their values can be increased by either increasing crop yield through better method of pest and disease control, plant breeding or decreasing evapotranspiration. Bekele and Tilahun [2] reported the positive effect of water stress at two growth stages of 
onion. In contrast, Nigatu [16] reported no significant improvement in irrigation water use efficiency resulting from irrigation deficit. Under conditions of water shortage, the best growth stages at which to achieve maximum water savings in the irrigation of onion (cv: Bombay Red) without yield reductions exceeding $31 \%$ are development (bulb formation) and maturity stages at which $50 \%$ of water requirement is applied.

\subsection{Mulch cover effects}

Mulches can be composed of plant materials or they may be synthetic mulches consisting of plastic sheets (Allen et al. [1]). The sheets are generally transparent, white or black. Colour as observed by Allen et al. [1] influences albedo mainly during the early stage of crops. Plastic mulches substantially reduce evaporation of water from the soil surface especially under trickle/drip irrigation. Among its advantages in use is increase in soil temperature, reduced fertilizer leaching, reduced evaporation, cleaner product and reduced weed problems. Higher initial cost and management are some of its disadvantages. Studies reported in Allen et al. [1] indicated that the average approximate reductions in crop coefficient, Kc and surface evaporation for five horticultural crops (squash, cucumber, cantaloupe, watermelon and tomato) under complete plastic mulch compared with no mulch using drip irrigation system was $10-30 \%$ and $50-80 \%$ respectively. Douglas [4] reported yield increases over state average of four times for pepper, squash and watermelon; and three times for tomato when plastic mulch and drip irrigation were used.

\subsection{Drip irrigation system hydraulics}

Drip (or sometimes referred to as trickle) irrigation system derived its name from the manner in droplets reaches the soil surface. Michael [14] reported it as one of the latest of the systems and is become increasingly popular in areas with water scarcity and salt problems. Water from source passes through plastic pipes, constituting the main and laterals, into emitters positioned to supply each plant with the calculated water requirement at the same delivery rate. Pressure head losses are encountered in lines which result in uneven distribution of the discharges from the emitters. Mofoke et al. [15] reiterated that the most widely accepted hydraulic performance indices for assessing the drip irrigation system are emitter discharge, emitter flow rate variation, uniformity coefficient and emission uniformity.

\section{Materials and methods}

\subsection{Climatic and soils description of the study area}

The climate of the study area (Mekassa: located at latitude $8^{\circ} 24^{\prime} \mathrm{N}$, longitude $39^{\circ}$ $21^{\prime} \mathrm{E}$ and altitude $1,550 \mathrm{~m}$ above sea level) is characterized as semi arid, having a long term (1977-2006) mean annual rainfall of $791.7 \mathrm{~mm}$. The rainfall has a bimodal pattern with a short rain season from March to April, a dry spell, and a 
long rain season from July to September. The long term mean maximum and minimum temperatures range from $30.9^{\circ} \mathrm{C}$ in May to $26.2^{\circ} \mathrm{C}$ in August and from $16.2^{\circ} \mathrm{C}$ in June to $10.8^{\circ} \mathrm{C}$ in December respectively. Recorded mean maximum and minimum temperatures which occurred in October and December were $28.18^{\circ} \mathrm{C}$ and $8.19^{\circ} \mathrm{C}$ respectively. The highest duration of sunshine was 10.4 hours in December with the lowest of 6.34 hours in October. The mean relative humidity was highest in October at $57.42 \%$ and lowest at $44.71 \%$ in December. Wind speed measured with the cup anemometer mounted at $2 \mathrm{~m}$ height recorded the highest mean wind speed of $10.04 \mathrm{~m} . \mathrm{s}^{-1}$ in December while the lowest mean wind speed of $6.34 \mathrm{~m} \cdot \mathrm{s}^{-1}$ was in October. Pan evaporation was highest in December with a mean value of $7.27 \mathrm{~mm}$.

\subsection{Soil characteristics at site}

The soil at the site is classified as Haptic Andosol with a characteristic feature of deep pumice or volcanic soil type having a high water retention capacity (Tesfaye and Walker, 2004) as cited by Nigatu [16]. A composite sample was collected at depth of 0-60 $\mathrm{cm}$ from the site and analyzed for physical and chemical characteristics at the Ethiopian National Soils Laboratory. The results show that the soil is loam in texture with a mean bulk density of $1.11 \mathrm{gm} . \mathrm{cm}^{3}$ and slightly alkaline with a pH of 7.89 and an EC of $0.208 \mathrm{dS} . \mathrm{m}^{-1}$. The soil was found suitable for irrigation. The soil was also assessed for infiltration using the Double Ring Infiltrometer.

\subsection{The experiment}

The two factors for investigation in the experiment were deficit irrigation at four levels $(0,25,50$ and $75 \%$ of Total Available Water, TAW) combined in a randomized complete block design with four types of mulch covers (no mulch, tef straw mulch, black and clear plastic mulches). These constituted sixteen treatments each laid in plots $1.8 \mathrm{~m} \times 5 \mathrm{~m}$. Each treatment was replicated three times, totalling forty eight plots covering a gross area of 0.086 ha.

\subsubsection{Field operation}

Onion seeds (Allium Cepa, L. Cv: Red Bombay) at the rate of $3 \mathrm{~kg}^{-\mathrm{ha}^{-1}}$ were sown on six seed beds $1 \mathrm{~m} \times 5 \mathrm{~m}$ to raise the seedlings required at a nursery close to the site on August 28, 2008. Nursery bed management according to the recommendations of the Experiment Station were followed. At seven weeks after sowing when the seedlings were about $10-15 \mathrm{~cm}$ high and had three true leaves, they were transplanted to $40 \mathrm{~cm}$ wide planting beds at intra-row and inter-row spacings of $10 \mathrm{~cm}$ and $20 \mathrm{~cm}$ respectively. Prior to transplanting, soil moisture content at depths up to $30 \mathrm{~cm}$ were determined using the gravimetric method and one irrigation applied to raise the moisture content of the soil one day before transplanting to field capacity level. Transplanting was done on October 20, 2008. After transplanting, full irrigation to restore soil moisture content to field capacity, based on effective rooting depth of $15 \mathrm{~cm}$, was given to all treatment plots. On 11 November, 2008, the irrigation and mulch treatments were imposed. 
Fertilizers and pest control chemicals were applied based on recommendations of the Research Station. Urea at the rate of $100 \mathrm{~kg} \cdot \mathrm{ha}^{-1}$ was applied between rows in two equal doses at the time of transplanting and at 4 WAT. A uniform dose of Diammonium phosphate (DAP) at the rate of $200 \mathrm{~kg} \cdot \mathrm{ha}^{-1}$ was applied and incorporated in the soil before transplanting. Pesticides chemicals were applied at 3, 4, 5 and 8 WAT. Three hand-hoe weeding were carried out at 4, 6 and 10 WAT. The crop was harvested 18 WAT on January 31, 2009 when the tops of more than $50 \%$ of plants had fallen over.

\subsubsection{Irrigation water source}

Rainwater harvested from farm roads and stored in a $50 \mathrm{~m}^{3}$ capacity underground tank, $6 \mathrm{~m}$ deep, was the main source of the irrigation water. A $50 \mathrm{~mm}$ diameter petrol engine pump was used to lift water from the underground tank to a $1.5 \mathrm{~m}^{3}$ capacity elevated tank, $2.5 \mathrm{~m}$ above ground. Pump capacity was calculated based on tank capacity and filling time.

\subsubsection{Drip system components}

Water from the elevated tank feeds into a supply line $20 \mathrm{~mm}$ diameter, $5 \mathrm{~m}$ long made from Low Density Polyethylene Pipe (LDPEP). A ball valve and a primary filter are fixed on the line and it terminated at a $20 \mathrm{~mm}, 19 \mathrm{~m}$ long mainline of the same material. Four sub mainlines each $34.6 \mathrm{~m}$ long, $20 \mathrm{~mm}$ diameter were connected to the mainline. Along each of the sub mainline, six tertiary lines each measuring $4.6 \mathrm{~m}, 20 \mathrm{~mm}$ were connected and it was on these tertiary lines that $12 \mathrm{~mm}$ diameter, $5 \mathrm{~m}$ long, $70 \mathrm{~cm}$ spaced laterals with inline emitters took off. There were 144 laterals altogether installed. The hydraulic characteristics of the system installed that were evaluated included: emitter flow rate, emitter flow rate variation, uniformity coefficient, emission uniformity, and application efficiency.

\subsubsection{Hydraulic characteristics of the system installed}

2.3.4.1 Emitter flow rate The average flow rate of the emitters used in the experiment was measured from plots in which catch cans were randomly assigned plots and volumes of flow caught over a time period. The discharge, or flow rate out of single outlet emitter at a specified head was estimated thus:

$$
q=\frac{V}{\Delta t}
$$

where $\mathrm{q}=$ single emitter discharge, litre/hour; $\mathrm{V}=$ volume of water collected from emitter, litres; and $\Delta t=$ time duration of discharge collection, hour

2.3.4.2 Emitter flow rate variation Emitter flow rate variation was simply computed as:

$$
q_{\mathrm{var}}(\%)=100\left(\frac{q_{\max }-q_{\min }}{q_{\max }}\right)
$$


where $\mathrm{q}_{\mathrm{var}}=$ emitter flow rate variation, $\% ; \mathrm{q}_{\max }=$ the maximum emitter flow rate along a lateral, litre/hour; and $\mathrm{q}_{\min }=$ the minimum emitter flow rate along a lateral, litre/hour.

2.3.4.3 Uniformity coefficient Uniformity coefficient was calculated using the Christiansen coefficient of uniformity formula given in Michael [14] as:

$$
U C(\%)=100\left(1.0-\frac{\Sigma_{x}}{q n}\right)
$$

where UC $(\%)=$ Uniformity coefficient, $\% ; \mathrm{q}=$ average discharge of the emitters, litre/hour; $\mathrm{n}=$ number of emitters; and $\sum \mathrm{x}=$ sum of the individual deviations of observed flow from the average discharge, litre/hour.

2.3.4.4 Emission uniformity The formula given by Howell and Hiller [9] cited in Michael [14] as used to estimate emission uniformity as:

$$
E u(\%)=100\left(\frac{q_{\text {low quarter }}}{q}\right)
$$

where $\mathrm{Eu}=$ Emission uniformity in $\% ; \mathrm{q}_{\text {low quarter }}=$ average discharge rate of the low quarter of the number of emitters observed, litre/hour; and $\mathrm{q}=$ average discharge rate of all observed emitters, litre/hour.

2.3.4.5 Application efficiency The overall application efficiency of the drip irrigation system was estimated from the relationship of Vermeiren and Jobling [18] given as:

$$
E a(\%)=K s . E u
$$

where Ea $=$ Application efficiency, $\% ; \mathrm{Ks}=$ Average water stored in the root zone over average depth of water applied and is a coefficient which expresses the storage efficiency of the soil taking into account the pressure variation in the drip system $(\mathrm{Ks}=1$ for loam soil) as in Vermeiren and Jobling [18] and $\mathrm{Eu}=$ as given in eq. (4).

\subsubsection{Water use and water use efficiencies}

Soil water use in the experiment was obtained principally from routine measurements of soil moisture content by the gravimetric method and use of Neutron probe meter. For the soil depth of $0-15 \mathrm{~cm}$, soil samples were collected with soil auger just before irrigation and one day after irrigation to compute soil water contents as: 


$$
S W=\Theta v \cdot Z=\Theta m \cdot B d \cdot Z=\frac{(F W-D W)}{D W} \cdot B d \cdot D z
$$

where SW $=$ Soil water content in the soil layer $(0-15 \mathrm{~cm}), \mathrm{cm} ; \Theta v, \Theta m=$ volumetric and gravimetric moisture contents in the depth in $\mathrm{cm}^{3} / \mathrm{cm}^{3}$ and $\mathrm{g} / \mathrm{g}$ respectively; $\mathrm{Dz}=$ depth of soil layer, $\mathrm{cm} ; \mathrm{Bd}=$ Bulk density of the soil, $\mathrm{g} / \mathrm{cm}^{3}$; and $\mathrm{FW}, \mathrm{DW}=\mathrm{Wet}$ and dried weights of soil sample, $\mathrm{g}$.

For soil layer below $15 \mathrm{~cm}$ depth, the Neutron Probe meter (Model: 503 DR CPN Hydro Probe) with forty eight access tubes made of $5 \mathrm{~cm}$ diameter, $150 \mathrm{~cm}$ long aluminium pipes were used to obtain soil water content up to depths of $40 \mathrm{~cm}$ in increments of $7.5 \mathrm{~cm}$. A calibration equation using the method in Eze et al. [6] was programmed into the probe so as to obtain direct readout moisture content in $\mathrm{mm}$.

Total available water is the water held in the root zone depth at moisture contents defined as field capacity (upper limit) and permanent wilting point (lower limit). In the experiment, upper limits of soil moisture contents were fixed at $0,25,50$ and $75 \%$ of TAW. Water use by the onion was therefore calculated based on change in soil moisture. The design of drip system predicated on zero runoff and deep percolation losses. The net depth of irrigation water applied was based on the moisture depleted from storage to satisfy actual crop evapotranspiration minus any rainfall in the interval plus leaching fraction (leaching was not considered in the study as the soil was non-saline). Effective rainfall was accounted for by the method suggested by FAO [7]. Gross depth of irrigation was calculated taking into account application efficiency of the system. Water use efficiency is a measure of crop water productivity which Michael [14] suggested can be measured in the form of:

$$
C W U E=\frac{Y}{C W U}
$$

where $\mathrm{CWUE}=$ Crop water use efficiency, $\mathrm{kg} \cdot \mathrm{m}^{-3} ; \mathrm{Y}=\mathrm{Crop}$ yield, $\mathrm{kg} \cdot \mathrm{ha}^{-1}$; and $\mathrm{CWU}=$ Crop water use, $\mathrm{mm}$

and

$$
I W U E=\frac{Y}{I W U}
$$

where IWUE $=$ Irrigation water use efficiency, $\mathrm{kg} \cdot \mathrm{m}^{-3} ; \mathrm{Y}=$ Crop yield, $\mathrm{kg} \cdot \mathrm{ha}^{-1}$; and IWU $=$ Irrigation water use, $\mathrm{m}^{3} \cdot \mathrm{ha}^{-1}$.

\section{Results and discussion}

\subsection{Emitter flow rate and flow rate variation}

The results in Table 1 show emitter flow rate as affected by the number tested at a time using the catch can test method. At an operating pressure head of $2.5 \mathrm{~m}$, 
the average emitter flow rate was 0.6045 litre/hr while mean maximum and mean minimum values were 0.656 and $0.566 \mathrm{litre} / \mathrm{hr}$ respectively. The average obtained, though at a higher pressure head, was lower when compared with the manufacturer's specification of $1.3 \mathrm{litre} / \mathrm{hr}$ at a pressure head of $1.0 \mathrm{~m}$. The mean coefficient of variation obtained for the results was 4.60 , indicating relatively low variations of the mean.

Table 1: $\quad$ Average, maximum and minimum emitter flow rates as affected by the number of treatments tested at a time using catch cans.

\begin{tabular}{|c|c|c|c|c|c|c|}
\hline & \multicolumn{5}{|c|}{ Number of treatment plots tested at a time } \\
\cline { 2 - 7 } Parameters & 48 & 24 & 18 & 9 & 3 & Average \\
\hline $\begin{array}{c}\text { Average emitter } \\
\text { flow rate, litre/hr }\end{array}$ & 443.4 & 624.9 & 663.6 & 648.2 & 642.2 & 604.5 \\
\hline $\begin{array}{c}\text { Maximum emitter } \\
\text { Flow rate, litre/hr }\end{array}$ & 480.0 & 670.0 & 760.0 & 680.0 & 680.0 & 656.0 \\
\hline $\begin{array}{c}\text { Minimum emitter } \\
\text { flow rate, litre/hr }\end{array}$ & 410.0 & 580.0 & 620.0 & 610.0 & 610.0 & 566.0 \\
\hline $\begin{array}{c}\text { Coefficient of } \\
\text { variation, C.V. \% }\end{array}$ & 5.10 & 5.40 & 5.80 & 3.80 & 3.80 & 4.60 \\
\hline
\end{tabular}

\subsection{Emitter flow rate variation, uniformity coefficient, emission uniformity and application efficiency}

The average emitter flow rate variation along laterals was $13.7 \%$, as shown in Table 2. This value closely agreed with the findings in Michael [14] and Jensen [11] which stated that in drip systems, the average variation in discharge rate of individual emitters in a whole field should not exceed $20 \%$.

Table 2: Emitter flow rate variation, uniformity coefficient, emission uniformity and application efficiency as affected by the number of treatments tested at a time using catch cans.

\begin{tabular}{|c|c|c|c|c|c|c|}
\hline & \multicolumn{5}{|c|}{ Number of treatment plots tested at a time } \\
\cline { 2 - 7 } Parameters & 48 & 24 & 18 & 9 & 3 & Average $^{\mathrm{b}}$ \\
\hline $\begin{array}{c}\text { Emitter flow rate } \\
\text { variation, \% }\end{array}$ & 14.6 & 13.4 & 18.4 & 11.6 & 10.3 & 13.7 \\
\hline $\begin{array}{c}\text { Uniformity } \\
\text { coefficient, \% }\end{array}$ & 95.6 & 95.7 & 95.3 & 96.4 & 96.8 & 96.0 \\
\hline $\begin{array}{c}\text { Emission } \\
\text { Uniformity, \% }\end{array}$ & 93.1 & 93.6 & 94.0 & 95.0 & 96.0 & 94.4 \\
\hline $\begin{array}{c}\text { Application } \\
\text { Efficiency, \% }\end{array}$ & 93.1 & 93.6 & 94.0 & 95.0 & 96.0 & 94.4 \\
\hline
\end{tabular}

${ }^{a}$ While testing specific treatments, gate valves for the others are closed.

${ }^{\mathrm{b}}$ Each treatment had 3 plots due to replication. 
Over the five separate tests, the average emission uniformity was found to $94.4 \%$ while the mean of the uniformity coefficient was $96 \%$, signifying even distribution of water throughout the system. These results are supported by Merriam and Keller [13] who stated that a drip system with both emission uniformity and uniformity coefficient of $85 \%$ or greater, and with a discharge variation of less than $20 \%$ should be considered satisfactory.

The application efficiency obtained averaged 94.4\%; this compared favourably to the results of Sijali [17] and IDN [10] who stated that drip irrigation systems are typically about $90 \%$ efficient as compared to sprinklers that are about $75 \%$ efficient.

\subsection{Deficit irrigation and mulch effects on bulb yield and seasonal water use}

The highest marketable bulb yield of 37.2 t.ha $^{-1}$ was obtained at the $0 \%$ deficit irrigation level and the lowest mean yield of 24.32 t.ha $^{-1}$ recorded at $75 \%$ level of irrigation deficit as presented in Table 3 . The yield differences were significant at $1 \%$ level of probability. The yield reductions with increased deficit irrigation levels from 0 to 25,50 and $75 \%$ were 16,26 , and $34.6 \%$ respectively which resulted from corresponding reductions of applied irrigation water of 14, 29 and $47 \%$.

Effect of deficit levels on Crop water use and irrigation water use revealed significant differences in seasonal values of the water use. In a nutshell, allowing for no deficit, an onion crop in the Central Rift Valley requires $527.18 \mathrm{~mm}$ of irrigation water per season to yield 37.2 thaa $^{-1}$. But, imposing a deficit level of $75 \%$ TAW the yield obtainable drops to 24.32 t.ha $^{-1}$. These results, up to deficit levels of 50\%, tally with Doorenbos and Kassam [3] report which stated that for an optimum yield, onion requires $350-550 \mathrm{~mm}$ of water.

Use of mulch had resulted in significant yield differences $(\mathrm{p}=5 \%)$. Onion yield under straw mulch, though at par with the plastic mulches, out-yielded bare soil (no mulch). No yield advantage was observed using clear as against black mulch. Seasonal water uses were significantly reduced under mulches (straw $>$ clear plastic $>$ black plastic) than with bare soil which resulted in over 400 mm per season.

Though the data showed no significant differences resulting from the interaction of irrigation deficit and mulch covers, the combination $\mathrm{I}_{0} \mathrm{M}_{1}(0 \%$ deficit level, straw mulch) yielded highest, close to 40 t.ha ${ }^{-1}$.

\subsection{Deficit irrigation and mulch effects on water use efficiencies}

Crop and Irrigation water use efficiencies were highest at the $75 \%$ irrigation water deficit at which 14.52 and $13.50 \mathrm{~kg} / \mathrm{m}^{3}$ were obtained respectively as Means followed by the same letter(s) in a column of any treatment group are not statistically different at the $5 \%(*)$, or $1 \%(* *)$ probability level using the Duncan Multiple Range Test. ns $=$ not significant.

$\mathrm{I}_{0}=0 \%$ deficit, $\mathrm{I}_{1}=25 \%$ deficit, $\mathrm{I}_{2}=50 \%$ deficit, $\mathrm{I}_{3}=75 \%$ deficit, $\mathrm{M}_{\mathrm{o}}=$ no mulch, $\mathrm{M}_{1}=$ Straw mulch, $\mathrm{M}_{2}=$ clear plastic mulch, $\mathrm{M}_{3}=$ black plastic mulch.

CWUE $=$ Crop water use efficiency, IWUE $=$ Irrigation water use efficiency. 
Table 3: $\quad$ Onion bulb yield, crop water use, irrigation water use, CWUE and IWUE as affected by deficit irrigation and mulch covers at Melkassa in the 2008/2009 dry season.

\begin{tabular}{|c|c|c|c|c|c|}
\hline Treatments & $\begin{array}{l}\text { Marketable } \\
\text { bulb yield } \\
\left(\text { t.ha }^{-1}\right)\end{array}$ & $\begin{array}{l}\text { Crop water } \\
\text { use (mm } \\
\text { /season) }\end{array}$ & $\begin{array}{l}\text { Irrigation } \\
\text { water use } \\
\text { (mm/season) }\end{array}$ & $\begin{array}{l}\text { CWUE } \\
\left(\mathrm{kg} / \mathrm{m}^{3}\right)\end{array}$ & $\begin{array}{l}\text { IWUE } \\
\left(\mathrm{kg} / \mathrm{m}^{3}\right)\end{array}$ \\
\hline \multicolumn{6}{|l|}{\begin{tabular}{|l|} 
Deficit irrigation \\
levels (\%)
\end{tabular}} \\
\hline$I_{0}$ & $37.20 \mathrm{a}$ & $490.28 \mathrm{a}$ & $527.18 \mathrm{a}$ & $11.51 \mathrm{~b}$ & $10.70 \mathrm{~b}$ \\
\hline $\mathrm{I}_{1}$ & $31.23 \mathrm{~b}$ & $420.38 b$ & $452.02 b$ & $11.20 \mathrm{~b}$ & $10.41 \mathrm{~b}$ \\
\hline $\mathrm{I}_{2}$ & $27.39 c$ & $349.25 \mathrm{c}$ & $375.53 \mathrm{c}$ & $11.86 \mathrm{~b}$ & $11.03 b$ \\
\hline $\mathrm{I}_{3}$ & $24.32 d$ & $259.73 d$ & $279.28 \mathrm{~d}$ & $14.52 \mathrm{a}$ & $13.50 \mathrm{a}$ \\
\hline Significance level & $* *$ & $* *$ & ** & $* *$ & $* *$ \\
\hline \multicolumn{6}{|l|}{ Mulch covers } \\
\hline $\mathrm{M}_{\mathrm{o}}$ & $28.27 b$ & $417.77 \mathrm{a}$ & $449.21 \mathrm{a}$ & $10.29 \mathrm{c}$ & $9.57 \mathrm{c}$ \\
\hline $\mathrm{M}_{1}$ & $31.71 \mathrm{a}$ & $353.25 \mathrm{~b}$ & $379.84 \mathrm{~b}$ & $13.89 \mathrm{a}$ & $12.92 \mathrm{a}$ \\
\hline $\mathrm{M}_{2}$ & $30.12 \mathrm{ab}$ & $364.84 \mathrm{~b}$ & $392.30 \mathrm{~b}$ & 12.78ab & $11.88 \mathrm{ab}$ \\
\hline & $30.04 a b$ & $383.77 \mathrm{~b}$ & $412.66 \mathrm{~b}$ & $12.13 b$ & $11.28 b$ \\
\hline Significance Level & $*$ & $*$ & & & $* *$ \\
\hline \multicolumn{6}{|l|}{$\begin{array}{l}\text { Interaction (deficit } \\
\mathrm{x} \text { mulch) }\end{array}$} \\
\hline $\mathrm{I}_{\mathrm{o}} \mathrm{M}_{\mathrm{o}}$ & 34.94 & 535.84 & 576.16 & $9.85 \mathrm{~d}$ & $9.16 \mathrm{~d}$ \\
\hline $\mathrm{I}_{0} \mathrm{M}_{1}$ & 39.46 & 449.60 & 483.44 & $13.17 \mathrm{bc}$ & $12.25 \mathrm{bc}$ \\
\hline $\mathrm{I}_{0} \mathrm{M}_{2}$ & 37.02 & 462.69 & 497.52 & $12.08 \mathrm{~cd}$ & $11.13 \mathrm{~cd}$ \\
\hline $\mathrm{I}_{\mathrm{o}} \mathrm{M}_{3}$ & 37.38 & 512.97 & 551.58 & $10.93 \mathrm{~cd}$ & $10.17 \mathrm{~cd}$ \\
\hline $\mathrm{I}_{1} \mathrm{M}_{\mathrm{o}}$ & 30.24 & 454.39 & 488.59 & $10.00 \mathrm{~d}$ & $9.30 \mathrm{~d}$ \\
\hline $\mathrm{I}_{1} \mathrm{M}_{1}$ & 32.86 & 402.40 & 432.69 & $12.28 \mathrm{~cd}$ & $11.42 \mathrm{~cd}$ \\
\hline $\mathrm{I}_{1} \mathrm{M}_{2}$ & 31.19 & 406.79 & 437.41 & $11.48 \mathrm{~cd}$ & $10.67 \mathrm{~cd}$ \\
\hline $\mathrm{I}_{1} \mathrm{M}_{3}$ & 30.65 & 417.92 & 449.38 & $11.03 \mathrm{~cd}$ & $10.26 \mathrm{~d}$ \\
\hline $\mathrm{I}_{2} \mathrm{M}_{\mathrm{o}}$ & 26.84 & 365.40 & 392.90 & $11.10 \mathrm{~cd}$ & $10.33 \mathrm{~cd}$ \\
\hline $\mathrm{I}_{2} \mathrm{M}_{1}$ & 28.63 & 334.01 & 359.15 & $12.97 \mathrm{bc}$ & $12.06 \mathrm{bc}$ \\
\hline $\mathrm{I}_{2} \mathrm{M}_{2}$ & 27.11 & 343.70 & 369.57 & $11.87 \mathrm{~cd}$ & $11.04 \mathrm{~cd}$ \\
\hline $\mathrm{I}_{2} \mathrm{M}_{3}$ & 26.96 & 353.87 & 380.50 & $11.49 \mathrm{~cd}$ & $10.69 \mathrm{~cd}$ \\
\hline $\mathrm{I}_{3} \mathrm{M}_{\mathrm{o}}$ & 21.07 & 315.47 & 339.21 & $10.20 \mathrm{~d}$ & 9.49d \\
\hline $\mathrm{I}_{3} \mathrm{M}_{1}$ & 25.89 & 226.97 & 244.06 & $17.14 \mathrm{a}$ & $15.94 a$ \\
\hline $\mathrm{I}_{3} \mathrm{M}_{2}$ & 25.14 & 246.17 & 264.70 & $15.68 \mathrm{a}$ & $14.58 \mathrm{a}$ \\
\hline $\mathrm{I}_{3} \mathrm{M}_{3}$ & 25.18 & 250.32 & 269.16 & 15.06ab & $14.00 \mathrm{ab}$ \\
\hline Significance Level & ns & Ns & ns & $*$ & $*$ \\
\hline CV $(\%)$ & 7.20 & 9.68 & 9.68 & 11.1 & 11.1 \\
\hline
\end{tabular}

CWUE and IWUE. The other levels were statistically equal. Singular effect of use of mulch showed the straw mulch as the best material, though at par with 
clear plastic (1\% level). Bare soil (no mulch) was not efficient in conserving water. The interaction of deficit irrigation and mulch showed there were significant differences in efficiency values when tested at the 5\% level. At $\mathrm{I}_{3} \mathrm{M}_{1}$, the highest CWUE of $17.14 \mathrm{~kg} / \mathrm{m}^{3}$ and IWUE of $15.94 \mathrm{~kg} / \mathrm{m}^{3}$ were obtained. The least was at $\mathrm{I}_{0} \mathrm{M}_{\mathrm{o}}$. These results show the positive effect of mulch covers even with deficit levels up to $75 \%$.

\section{Conclusions}

Results from the present level of work show that combining irrigation deficit with use of mulch covers, particularly straw mulch that is in abundance with farmers, presents a sustainable strategy for onion production in the semi-arid areas of Ethiopia. Use of plastic mulches did not show any superiority over straw mulches; laying difficulties with these materials in windy conditions present challenges to farmers. Imposing irrigation deficit levels beyond $50 \%$ is not advisable as marketable bulb yield and bulb sizes decline. The drip system technology used in the study is at entry level for farmers and it is aptly demonstrated from this work that the amount of water savings that can be achieved is substantial when compared to other irrigation systems.

\section{Acknowledgements}

The authors of this paper wish to acknowledge with thanks the support provided by Sasakawa Africa Fund for Extension Education (SAFE). Similar thanks go to the Agricultural Extension Department of the Federal Ministry of Agriculture and Rural Development of Ethiopia for approving the study leave of the second author. The assistance rendered by Melkassa Agricultural Research Centre and the National Soil Testing Centre in the form of use of research land, field staff, equipment and analysis at no cost is very much appreciated.

\section{References}

[1] Allen, R.G., Pereira, L.S., Raes, D. \& Smith, M. Crop evapotranspiration. Guidelines for computing crop water requirements. FAO Irrig. Drain, Paper No. 56. FAO. Rome, Italy. 300pp. 1998.

[2] Bekele, S. \& Tilahun, K. Regulated deficit irrigation scheduling of onion in a semi-arid region of Ethiopia. Agricultural water Management. 89: pp.148-152, 2007.

[3] Doorenbos, J. \& Kassam, A. Yield response to water. Irrigation and Drainage Paper No. 33. FAO. Rome, Italy. 193pp. 1979.

[4] Douglas, C.S. Using plastic mulches and drip irrigation for vegetable production. http://www.ces.ncsu.edu/depts/hort visited 06/12/2007.

[5] EARO. Dry land Agricultural Research Strategic Plan, Addis Ababa, Ethiopia. 1999. 
[6] Eze, P.C., Alhassan, A.B., Kundiri, A.M. \& Mamman, E. Neutron moisture calibration - a tool for effective soil moisture monitoring. Proc. of the $13^{\text {th }}$ National Irrigation and Drainage Seminar., eds. I.U. Abubakar \& M.K. Othman, Ahmadu Bello University Press: Zaria Nigeria, pp. 232-235, 2007.

[7] FAO. Irrigation water management: Irrigation water needs. Training Manual No. 3. Rome, Italy. 1986.

[8] FAO. Deficit Irrigation Practice, Water Report 22. Rome, Italy. 88p. 2000.

[9] Howell, T.A. \& Hiller, E.A. Optimization of water use efficiency under high frequency irrigation - I. Evapotranspiration and yield relationship. Transaction: ASAE, 15(5), pp. 873-878, 1975.

[10] IDN (International Development Enterprise). Technical Manual for affordable micro irrigation technology. http://www.ide.international.org visited 14/06/2007.

[11] Jensen M.E. (ed.) Design and operation of farm irrigation systems, ASAE Monograph 3, American Society of Agricultural Engineers, St Joseph, Michigan, pp. 447-500. 1983.

[12] MOA. The five year action plan of soil and water conservation activities. Forest and Wildlife, Soil and Land Use Technologies Regulatory Department, Federal Ministry of Agriculture, Addis Ababa, Ethiopia. 2001.

[13] Merriam, M. \& Keller, J. Farm irrigation system evaluation: a guide for Management. Printed in the United States of America, Logan, Utah. 1978.

[14] Michael, A.M. Irrigation: Theory and Practice. Vikas Publishing House Pvt. Ltd. New Delhi, 801pp. 1978.

[15] Mofoke, A.L.E., Adewumi, J.K., Mudiare, O.J. \& Ramalan, A.A. Design, contruction and evaluation of an affordable continuous-flow drip irrigation system. http://www.vl-irrigation.org visited 6/11/2007.

[16] Nigatu, A.W. Identification of the critical water requiring growth stage on Onion (Allium cepa L.) for bulb production in the Central Rift Valley. MSc. Thesis. Haramaya University. Ethiopia. 2008.

[17] Sijali, I.V. Drip irrigation: Options for smallholder farmers in eastern and southern Africa. RELMA Technical Handbook Series 24. Nairobi, Kenya. 2001.

[18] Vermeiren, L. \& Jobling, G.A. Localized irrigation: design, installation, operation and evaluation. Irrigation and Drainage Paper 36, FAO, Rome, Italy. 1980. 